IRA-International Journal of Education \& Multidisciplinary Studies ISSN 2455-2526; Vol.04, Issue 03 (2016) Pg. no. 381-386

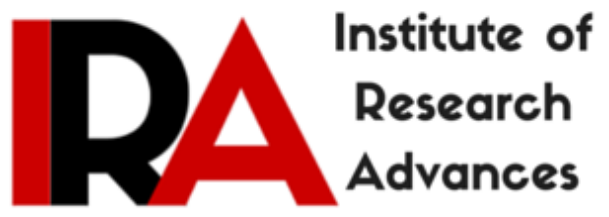

\title{
Student-Centric Approach to Field Work in Social Work Education
}

\author{
Dr. Anjali Dhengle \\ PhD.(Social Work), TISS, Mumbai. \\ Lecturer (Social Work), Devi Ahilya Vishwavidyalya, Indore, (M.P.)
}

Type of Review: Peer Reviewed

DOI: http://dx.doi.org/10.21013/jems.v4.n3.p4

\section{How to cite this paper:}

Dhengle, A. (2016). Student-Centric Approach to Field Work in Social Work Education. IRA International Journal of Education and Multidisciplinary Studies (ISSN 2455-2526), 4(3), 381-386. doi:http://dx.doi.org/10.21013/jems.v4.n3.p4

(C) Institute of Research Advances

\section{(cc) EY-No}

This work is licensed under a Creative Commons Attribution-Non Commercial 4.0 International License subject to proper citation to the publication source of the work.

Disclaimer: The scholarly papers as reviewed and published by the Institute of Research Advances (IRA) are the views and opinions of their respective authors and are not the views or opinions of the IRA. The IRA disclaims of any harm or loss caused due to the published content to any party. 


\begin{abstract}
The paper is discussing about philosophy of field work and its relevance in social work education. The paper covers the three main components of field work, namely the field work agency, students of social work and supervisors. The researcher is identifying students as the main component and emphasizing on student-centric approach to field work. This approach would facilitate students to play an active role and gain maximum from the learning from fields. This would also help in resolving many dilemmas and difficulties faced by the students. The other main players like the Institute supervisors and the field work agencies need to be sensitive towards this and adopt the student-centric approach, while guiding them on fields. The researcher further discusses the aspects important in adopting student-centric field work during the course of social work education.
\end{abstract}

Key Words: Social work education, Student-centric field work, Components of social field work

\title{
Introduction
}

Social Work education consists primarily of two main components, theory based knowledge and social skills development through field work. The social work skills are concerned with problem solving and are not mechanical in nature which are identifiable, can be acquired by watching others and belongs to set of job or to particular agency. Rather they are based on knowledge contained in the social and biological sciences pertaining to man and society (Gore, M.S., 1957). Field work is an opportunity to enhance one's social skills which is important for the social workers when it comes to serving the society. Thus one can see that theory coupled with field work assures to have in-depth and variety of exposures to students (Patford, J., 2012).

Field work in social work education is considered as a fundamental part of curriculum and has central importance (Gore, M.S., 1957; Mallick, A., 2007). It is based on Deweys' philosophy of learning by doing (Pathak, 1978) and regarded as critical transition period (Sclocombe, 1993) which prepares students to be proficient professional social workers. It is an opportunity to practice social work theory in the form of social work interventions on actual persons, organizations and communities (Patford, J., 2012). The experiences gained during the period of field work stay with students forever and make them capable future social worker (Mallick, A., 2007).

Field work yields many other advantages as well, apart from making the profession and the professionals more responsible; it also gives them a chance to grow on their maturity level and ethical values (Patford, J., 2012) and also equips them to face possible stress in social work occupation (Eisenberg, et. al., 1996). While learning in field, the students get a scope to assess their carrier choices and can judge their suitability for particular roles in particular setting. Field work is also concerns about individual students' sensibility, fears, learning but at the same time it is practice for them to allow their idiosyncrasy to nurture under group expectation and norms (Patford, J., 2012).

All these happen with the coordinated efforts of social work institutes, field work agencies and students. The field supervisors and the field work agency ensure to provide students with different type of clients and situations for their learning.

However it is observed widely that field work though a vital component of social work education has always lacked a scientific approach. The available literature on the subject, indicates that many studies have focused mainly on inter linkage of knowledge and practice, and on issues related to supervision of student. But very little attention had been paid to the learning process of students in the field work, on different teaching styles and so on (Noble, 1999; Lam, C. M., et., 2007; Mallick, A., 2007). 
Congruently Spencer and McDonald (1998), reports that there is insufficiency of knowledge in regard to incidents pertaining to students learning and their views about supervision. Insufficient attention has been diverted to the aspect of feedback from the students about their field work. The evaluation of or feedback received from students in the form of their own interest, values, interpretation of knowledge and practice integration, are key to improve on the field work approaches and to make it more systematic. With regard to evaluation of field work, students are the key components who can give valuable inputs in relation to their own interest, values, interpretation of knowledge and practice integration (Anspach,1991; Robinson, 1984). This provides a scope for more students' friendly techniques and/or approaches for field work.

\section{Components of field work}

The components of field work that is the students, the supervisors and the social agencies are discussed below to bring out the possible areas where they could go for a student-centric field work.

\section{Agency}

Maurya, M.R., (1962) expressed that to execute the idea of knowledge and practice based learning, students are placed in field agency or project for certain duration of time. A student is expected to relate to theory taught in the class to each and every situation he/she would face in the field. In order to be fair with this, a student should be absorbed by the agency as one of its members rather an outsider. However a caution should be taken that while doing so, the agency should not end up giving the students the tasks of its staff but rather should focus on providing to him/her suitable and varied field exposures. In this scenario, the role of schools/institutes comes in to picture to choose such agencies which are capable and willing to render such services. Through these purposive selection of field work agencies school would be able to prevent unsuccessful field work exposures for its students, where the students do not learn much. The agency supervisor may have their own work responsibilities because of which they may not be able to give quality time and supervision to students placed in their agencies. This sort of problems can sorted out with proper coordination with the school supervisors (M.S Gore, 1957)

\section{Students}

The extent to which field learning becomes successful depends on many factors but students and their characteristics play key role in the entire learning process. Moreover quality of professional relationship between student and supervisor is off due importance (Gore, M.S., 1957; Maurya, M.R., 1962; Mallick, A., 2007).

Gore M. S., (1957), has identified few of the characteristics of students placed in their first year of field work which needs supervisors' attention and expertise to deal with. This consideration can ensure structuring and strengthening of power relationship between student and supervisors (Mallick, A., 2007).

\section{Characteristics of students identifies by Gore M.S. in 1997 which are relevant to discuss even in $20^{\text {th }}$ century}

Most of the student entering to social work first year belongs to the late adolescent and early adulthood. In this age group to react hurriedly and to be judgmental is natural. These students may not be prepared for the ground realities and may feel anxious. Such students may have more dependency on their supervisors for sorting out their conflicts with the realities exposed during field work.

Secondly students come from varied backgrounds to have training in social work; this may lead to complications in regard to 'English' as a language of learning and instructions, coeducational nature of group, this in turn brings awkwardness, nervousness for the students. The students enter into a different environment and a lot is expected from them. Students react to this environment and expectations in their 
own natural way (Gore, M.S., 1957). As karmer, 1974, status that changes in role on students' part may rely on resemblance between academic teaching and filed experiences. It may also rely on students' features and their readiness to change (Cherniss, 1995).

In similar line Maurya, M.R., (1962) recognizes that there is need to be aware of the uniqueness of each student. Since student is the focal point of learning so one has to permit these differences in training process. Mallick, A., (2007), suggested many measures which facilitate active role of students in teaching-learning process. They are explained below:

- Students should be allowed to have their own preferences based on specialized interest in allotment of field work agencies. Even they should be given chance to explore their choices and to change if needed after test-placement of one day.

- There should be clarity about students' role and objective for which he/she has been placed to an agency. There should be arbitration about learning process between student and field work supervisors.

- Field work in social work education calls for more transparency in the form of students' participation in the formation of evaluation report at the termination of field work. It should also be signed by student concerned. Student should also have asses and freedom to discuss the records complied by field work supervisor for continues assessment of their student.

- On the part of supervisors lot of self evaluation in relation to their teaching style is demanded. So that they can manage their own way of giving instructions/supervise student learning task by having problem-solving approach. Supervisor should adapt his/her teaching style to the student's learning style.

- To understand teaching and learning style personal tutor should lead in dyad of power relationship of student and supervisor, so to have triangulation of all three component. This triangulation would help to consider mid-term changes of placement if needed.

As suggested by Mallick, A., (2007), student can also make full utilisation of field work training by maintaining records of the experiences, work accomplished and achievements in the field. This can help them to have gainful discussions with their supervisors and would facilitate their learning in the field. Student can also form peer support groups to get emotional support to handle dilemmas of the field and the problems faced by them (Kapoor, J.M., 1966),

\section{Supervisors}

Social work supervision is the process of training a less skilled (supervisee) person on the foundation of theoretical knowledge which is exchangeable to exercise on clients for their maximum benefits and to enable them to solve their own problems, by skilled person (supervisor) (Itzhaky, 2000).

When one talks about the theories of social work supervision, one sees that there is no agreement to follow one theory which is well thought off and most appropriate to follow. Nor there is any single allinclusive theory (Munson, 2002; Montigny, 2007). Because of this there are various understandings about ways of doing supervision which leads to ambiguity and complication about the matter (George Karpetis, 2010).

In the context of field supervision during field work, there are many things which should be paid attention. First of all it is the power relationship between the students and supervisors. To tackle this, they should make use of laid structures/norms to counterbalance power differential in the student-supervisor relationship.

Other reflections to be made are the problem faced by the students in the form of resistance to learn, struggle in managing their own emotional dilemmas which hinders the whole process of learning. Here the supervisors play an important role to counsel, motivate and encourage students for the field work 
(Maidment, J., and Crips, R. B., 2011). Other important aspect is the tension between supervisors and student regarding to evaluation of field work (Ernest, W.T. Chui., 2010), which needs to be assessed thoroughly. The relationship of student and supervisor is crucial in the gaining utmost practice learning experience in the field (Maidment, J., and Crips, R. B., 2011). Nehami Baum, 2011 found that good professional relation with supervisor was leading to feeling of gain, growth in terms of learning and mixed feelings on end of relation due to termination of field work by the student. Whereas there was feeling of sadness and loss in case of student describe this relation as poor or fair. Author further emphasised on improvement of supervisory process and ending of field work supervision.

The other important areas are the difficulties faced by the supervisors. When these difficulties are not addressed it may affect the learning process of students. The researcher tries to bring in to light few of the difficulties faced by supervisors which can be addressed by having specific objectives of field work, purposive selection of placement agencies and self-evaluation by supervisors. As explained by Gore, M.S., 1957 few of the difficulties are discussed below -

- School supervisors may face problem when agencies are not meeting learning expectation and when agency supervisors are not be able to understand the assignment done /implemented by students on client can lead to unnecessary interruptions. That's' the reasons for purposive selection agencies based on the quality of services, qualification of agency members.

- Problem with continuity and wide exposure of practical experience in each term may arise for this supervisors need to have strong networking and updating of information in regard to social work profession.

- Supervisor can face complexity in convincing well established agencies the purpose for which students can be placed with them for practical learning and even when agencies allows a staff member to supervise students, they do not follow the practise having regular contact with school in regard to students learning process. For this schools have to take extra efforts to have regular inspection and meetings, individual conference with agency supervisors. Should have to indulge in regular updating and networking with various agencies and organization to check the possibility of student's placement for field work.

\section{Conclusion}

This paper is an attempt to bring in to notice objectives and philosophy of field work and how it is vital component of social work education. Out of the three main components of field work namely agency, student and supervisor there is need to bring student-centric approach to have necessary changes in the learning process. There is need to pay attention on the problems coming up at agency and supervisors' level also. But at the same time student as the key component, their view and expectation are of due importance. At the same time student supervisors' power relation should be counter balanced in such way so to have maximum learning benefits for student. This consideration may help to produce more competent trained social workers who will be able to work for benefits of many, more efficiently and effectively.

\section{References}

- Anspach, R. (1991). Everyday methods for assessing organisational effectiveness. Social problems, 38(1),1-18.

- Cherniss, C. (1995). Beyond burnout, Rroutledge, New York.

- Eisenberg, M., Heycox, k. and Hughes. (1996). Fear of the personal: assessing students in practicum, Australian social work, 49 (4), 33-40. 
- Ernest. W.T. Chui. (2010). Desirability and Feasibility in Evaluating Fieldwork Performance: Tensions between Supervisors and Students, Social Work Education: The International Journal, 29(2), 171-187

- George, Karpetis. (2010). Field practice supervision of social work students: a psychodynamic view on the emotional context of the process and the setting during the client assessment phase, European Journal of Social Work, 13 (4), 503-522.

- Gore, M. S. (1957), Field work supervision in an Indian school of social work, Delhi, kingsway press.

- Itzhaky, H. (2000). The secret in supervision, Families in Society, 81(5), 529-537.

- Jane, Maidment., \& Beth, R. Crisp. (2011). The Impact of Emotions on Practicum Learning, Social Work Education: The International Journal, 30(4), 408-421.

- Kapoor, J.M. (1966). Resistance in social work education, Indian Journal of Social work, 27(1), 31-37.

- Kramer, M. (1974). Reality Shock, C.V. Mosby, St. Louis.

- Lam, C. M., Wong, H., and Leung, T. T. F. (2007). An unfinished reflexive journey: social work students' reflection on their placement experiences, British journal of social work, 37, 91-105.

- Mallick A., (2007). Field work training in social work curriculum reflections on learning and teaching, Indian journal of social work, 68,4, 573-580.

- Maurya, M.R., (1962). Field work training in social work, Indian journal of social work, 23 (1), 9-14.

- Montigny, G. (2007). Ethno methodology for social work, Qualitative Social Work, 6(1), 95-120.

- Munson, C. (2002). Handbook of Clinical Social Work Supervision, 3rd edn, Hawthorn Social Work, Practice, New York.

- Nehai, Baum. (2011). Social Work Students' Feelings and Concerns about the Ending of their Fieldwork Supervision, Social Work Education: The International Journal, 30(1), 83-97.

- Noble, C. (1999) The essential yet elusive project of developing field education as a legitimate area of social work inquiry, Issues in social work education, 19(1),2-16.

- Patford, J. (2012), Can I do social work and do I want to? Student perception of significant learning incidents during practica, Australian social work, 53 (2), 21-28.

- Pathak, S. (1978). Social welfare: health and family planning in India, New Delhi, Macmillan publication.

- Robinson, R. (1964). Different approaches to the evaluation of programs and services, Australian psychologist, 19 (2), 147-162.

- Slocombe, G. (1993). If field education is so vital, why isn't everyone doing it?' Australian social work, 46 (2), 42-49.

- Spencer, A., Mcdonald, C. (1998). Omissions and commissions: an analysis of professional field education literature, Australian social work, 51(4), 9-18. 